Mitteilungen der Österreichischen Geographischen Gesellschaft, 160. Jg., S. 241-258

(Annals of the Austrian Geographical Society, Vol. 160, pp. 241-258)

Wien (Vienna) 2018, https://doi.org/10.1553/moegg160s241

\title{
GEOINFORMATION
}

GEOGRAPHIC INFORMATION SCIENCE

\section{Automatic Identification of Bomb Craters ANd Their Potential Location}

\author{
Attila JuHÁSZ and Hajnalka NEUBERGER, both Budapest* \\ Initial submission / erste Einreichung: 02/2018; revised submission / revidierte Fassung: 11/2018; \\ final acceptance / endgültige Annahme: 12/2018 \\ with 7 figures and 5 tables in the text
}

\section{CONTENTS}

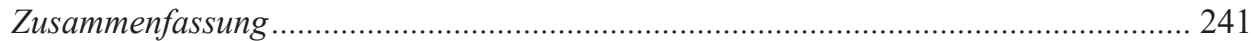

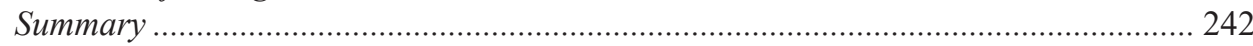

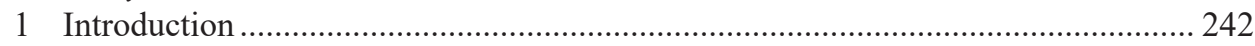

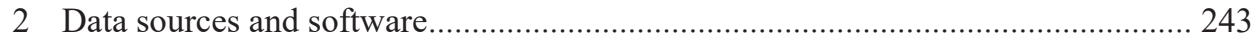

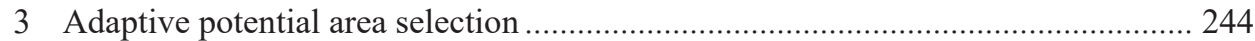

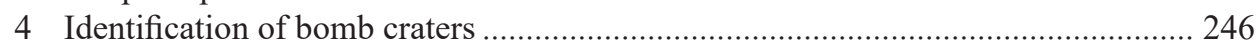

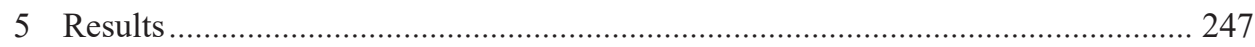

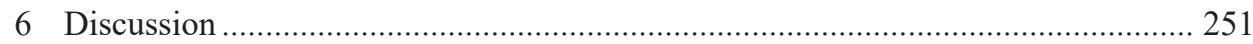

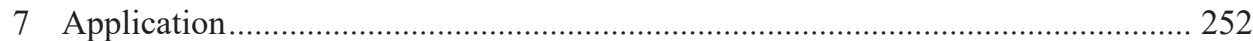

8 Conclusion and future research....................................................................... 255

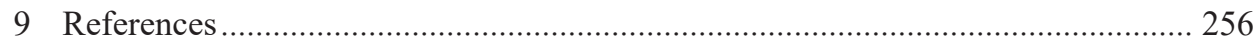

\section{Zusammenfassung}

AUTOMATISIERTE IDENTIFIZIERUNG VON BOMBENKRATERN UND IHRER POTENZIELLEN POSITION

LiDAR-Daten werden im Allgemeinen für archäologische, geographische und geologische Zwecke verwendet. In der modernen Archäologie erfolgte die Rekonstruktion von

* Attila Juhász, PhD, Hajnalka Neuberger, PhD candidate, both Department of Photogrammetry and Geoinformatics, Budapest University of Technology and Economics, Múegyetem rkt. 3, H-1111 Budapest, Hungary; email: juhasz.attila@epito.bme.hu; neuberger.hajnalka@epito.bme.hu 
Verteidigungslinien des Zweiten Weltkriegs durch Objektidentifikation und Kartierung. Die Erkennung und Identifizierung von Bombenkratern mithilfe von LiDAR-Daten kann diesen Rekonstruktionsprozess unterstützen. Das größte Problem ist in diesem Zusammenhang die Handhabung der enormen Zahl an dadurch ermittelten relevanten Daten. Daher besteht ein großer Bedarf, den gesamten Prozess der Detektion und Identifizierung zu automatisieren. In diesem Beitrag werden automatisierte Methoden vorgestellt, die entwickelt wurden, um die Detektion zu erleichtern und die relevanten Räume zu identifizieren und einzugrenzen. Darüber hinaus kann diese Methode auch bei anderen Aufgaben angewendet werden, z.B. bei Grabhügelerkennung oder zur Kartierung von Dolinen (Doline-Mapping).

Schlagwörter: GIS, LiDAR, Bildverarbeitung, Bombenkrater, Rekonstruktion militärischer Objekte, Archäoinformatik, Neuzeitarchäologie

\section{Summary}

LiDAR (Light Detection and Ranging) data are generally used for archaeological, geographical, and geological purposes. In modern age archaeology, military object identification and mapping are used to reconstruct World War II defense lines. This article argues that this reconstruction process can be supported by detecting and identifying the location of bomb craters using LiDAR data. Because of the large amount of such relevant data and the issues associated with their management, there is a need to automate the entire process of detection and identification. This article presents and discusses the methods that have been developed for this automation. These methods could also be applied for different research objectives using LiDAR data, such as to detect the location of burial mounds and to carry out mapping of doline formations.

Keywords: GIS, LiDAR, image processing, bomb craters, military object reconstruction, modern age archaeology

\section{Introduction}

Much research is based on the detection and identification of local significant elevation differences on the ground surface. For example, various archaeological objects (e.g. burial mounds), modern archaeological and military historical sites (e.g. bomb craters), and even certain typical geomorphological forms and phenomena (e.g. dolines) are often similar in shape and differ only in their size. GIS (Geographic Information System) and remote sensing technologies have been successfully applied to reconnaissance, identify and analyse these kinds of field objects. Furthermore, large amounts of high quality 3D data are available even free of charge, thanks to recent changes in data policies.

Excavations of burial mounds and places are the key research focus in traditional archaeology, because the funeral artefacts could reveal the relationships, habits and ethnicities of the people who had lived in the investigated area (GRAMMER et al. 2017). In geomorphological studies that focus on karstic areas, the investigation of doline forma- 
tions plays a key role. Their morphometric characteristics (area, perimeter, depth, roundness, compactness, horizontal stretching, ratio of the depth and perimeter, azimuth of the fore-axis) together with the territorial characteristics (number and density of dolines, doline distribution) are used to describe the investigated area (Telbisz et al. 2016). Furthermore, GIS is also effective in examining various surface erosion types (WIGAND and GEITNER 2010).

Nowadays, LiDAR (Light Detection and Ranging) is one of the most frequently used technologies in data acquisition procedures. Billions of 3D ground-points can be gathered, even in vegetation covered areas. Laser scanners are widely used for a variety of applications, including engineering (BERÉNYI 2010) pedestrian detection (BARSI et al. 2016), supporting autonomous vehicle mapping (BARSI et al. 2017), and even examining trees in dormancy (ZLINSZKY et al. 2017).

The LiDAR technology can also be integrated into historical military object reconstruction. Identification and map creation of the fortification elements are essential parts of a $20^{\text {th }}$ century military object-, environmental- and event-reconstruction (JUHÁsz and NeUberger 2016). Besides the visualisation and analysis of these fortified objects that remained, special risk and bomb maps can also be created, which can reveal unexploded bombs close to them (MARCHIONNI et al. 2013). Previously published research on similar topics has reported the almost exclusive use of archive aerial photographs. Machine learning based algorithms (BRENNER et al. 2018) and Marked Point process (KRUSE et al. 2017) were developed and applied to detect bomb craters on images. To our knowledge, LiDAR based bomb crater detection methods have not been published yet, but there is an example of LiDAR data based crater detection (SALAMUNIĆCAR and LONČARIĆ 2008).

In the future, LiDAR data could be used as the nationwide topographic core data, thanks to the rapidly evolving technology (VIRTANEN et al. 2017). Since 2015, Geiger mode LiDAR data is also available for commercial use (STOKER et al. 2016); these data can produce more accurate and denser point clouds much faster (up to $1000 \mathrm{~km}^{2} /$ hour) than the conventional linear LiDAR. However, this large amount of data also has challenges in the processing phases.

Our aim was to find an efficient method to process huge amounts of heterogeneous data in the GIS environment through a military example. During this research, an automated procedure was developed. It is able to select areas of interest from a large amount of integrated geodata and efficiently identify and count bomb craters with minimal userinteraction. Previous versions of the methods have been published (NEUBERGER et al. 2017; JuHÁsz and Neuberger 2018), and now the details of the further improvements are presented in this article. Finally, some examples are shown for the more general use of these methods.

\section{Data sources and software}

Data sources used in World War II military object mapping have been mostly archive aerial photographs combined with field measurements. However, shadows of objects, clouds and poor quality of the images can make the research more challenging. Con- 
versely, high resolution elevation data and precise DTMs (Digital Terrain Models) can be derived from airborne laser scanning (ALS) measurements, which can eliminate these difficulties. Because of these advantages, both the area selection and crater detection procedures are based on ALS data. Online links for hundreds of gigabytes of LiDAR data are now accessible thanks to the German pilot project made by North Rhine-Westphalia state (OpenGeodata NRW 2016). During the potential area selection procedure, LiDAR and OSM data (OpenStreetMap 2018) were downloaded for the German sample districts (Emmerich am Rhein; Rheine). Considering the accuracy of the forest mapping (uncertain border lines), the OSM database quality is adequate for this research, but it could be replaced with other digital topographic data.

The ArcGIS Model Builder was used to automate spatial data processing (ArcGIS ModelBuilder 2018). In this application, the models can be workflows that string together sequences of geo-processing tools, and the procedure can be executed several times without interaction by the user.

\section{Adaptive potential area selection}

For investigating large territories, the key task is to reduce the areas of interest as much as possible. Selecting specific areas to examine World War II objects is a challenging task, because these objects have disappeared in most places. During the decades since, urban areas have been rebuilt, new settlements have been established, infrastructure has been developed, and agricultural activities have covered former trenches, craters, and other signs of the war. These objects have only been preserved in forests and wooded areas (MERLER et al. 2005), and therefore, these areas were the focus of the research.

The procedure first involved downloading LiDAR and OSM data for a single state, and then, as part of pre-processing, the original datasets were adjusted for size and format. The UTM (Universal Transversal Mercator) reference system of the LiDAR data was used as the projection system of the process. The .xyz file format of the LiDAR data was transformed into .laz format, which resulted in radical file size reduction (ISENBURG 2013). The OSM 'forest' layer was selected and $1 \times 1 \mathrm{~km}$ vector tiles were created from the laz header files.

The development had two stages; the previous process worked effectively for those areas where the ratio of the wooded areas was relatively low to total investigated areas. Testing the Emmerich am Rhein sample data ( $6 \%$ forest coverage) the original data was reduced to $30 \%$, but when checking the Rheine dataset (20\% forest coverage) with the same method, the remaining data was still $75 \%$ of the original data (JuHÁsz and NEUBERGER 2018). The unified tile-size based calculation was the main disadvantage of the method, because a significant number of non-categorisable areas was left even after the morphological cleaning; thus the methodology was further improved. In the next stage of development, information content of files was already considered. The aim was to eliminate the non-informative areas in the dataset by adjusting tile creation. This was achieved by dividing the files that had low information content into smaller tiles. The adaptive tile selection optimised the ratio of the informative to noninformative areas (Fig. 1). 

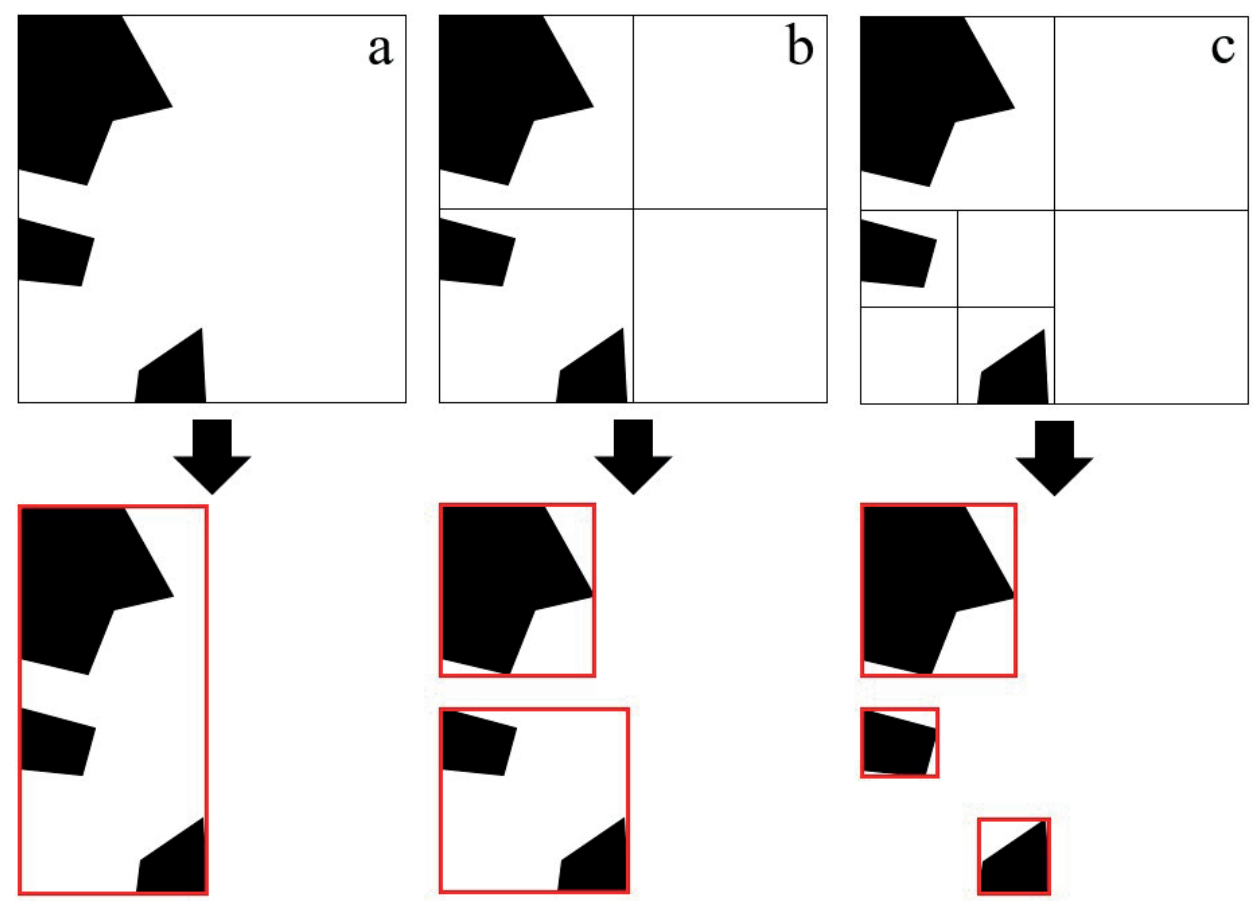

Source: Own images based on own process

Figure 1: Mask creation (a: $1 \mathrm{~km}^{2}$ tile; b: $0.25 \mathrm{~km}^{2}$ tile; c: adaptive mask)

The processing stages for adaptive tile creation were:

1. Downloading and pre-processing the OSM and LiDAR files;

2. Creating $1 \times 1 \mathrm{~km}$ tiles from the LiDAR header files;

3. Intersecting the OSM 'forest' layer and the $1 \mathrm{~km}^{2}$ tiles;

4. Creating raster masks with vector-raster conversion, where the forested areas are presented by black, and the non-informative areas by white;

5. Excluding empty raster masks from the process;

6. Calculating the masks' areas from the minimum boundary boxes of the forested areas;

7. Revising the masks: the masks with low forest ratio (compared to a threshold e.g 20\%) were divided into four parts, and the masks with the high forest ratio (compared to the same threshold) were kept;

8. Repeating the process from the second stage with $500 \times 500 \mathrm{~m}$ tiles, and if required with even smaller tiles, until each mask meets the forested/nonforested area ratio threshold.

9. Deleting masks or masks' parts that consist of a smaller size of 'forest' pixel clusters than the size of a crater. As a result, the number of investigated masks and the size of the masks were decreased (Fig. 2). 

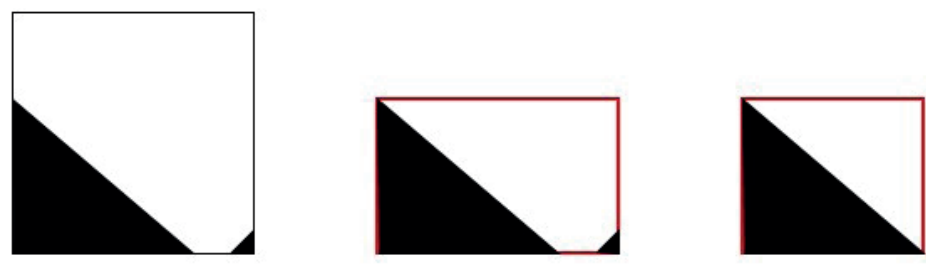

Source: Own images based on own process

Figure 2: Decreasing the mask's size by deleting the small 'forest' pixel cluster

\section{Identification of bomb craters}

Following the selection of the areas of interest, the next objective was to develop a process to identify bomb craters automatically. The five key stages of bomb crater detection are described below (stages 1-5) (NEUBERGER et al. 2017), and three new stages were added to the published process to increase efficiency (stages 6-8). Finding the optimal combination of the stages and refining the parameters also improved the previous version of the method. The earlier stages, without details, are:

1. Creating raster DTM with $1 \times 1 \mathrm{~m}$ horizontal resolution by kriging from LiDAR ground points;

2. Creating a smoothed trend surface by multiple use of $3 \times 3$ mean filter;

3. Subtracting the original DTM from the trend surface;

4. Creating a binary image based on the elevation difference threshold;

5. Cleaning the binary image of the noise and objects that are too large, and using morphological filters.

Checking circularity and distance transformation were also applied in the improved method; 1 m DTM resolution was considered, because the optimal values depend very heavily on DTM resolution.

6. Non-circular objects were excluded in order to reduce the number of falsely detected craters. The circularity of an object was calculated from the ratio of its area and the square of its perimeter. The circularity of a perfect circle has a value of 0.08 ; during this stage values between 0 and 0.07 were checked, and the optimal value was defined as 0.03 .

7. Morphological filters (erosion, dilatation and their combinations, opening and closing) were applied as filters to reduce noise, separate individual and joint elements, and identify intensity bumps and holes. During the improvement, the parameters and the combination of the filters and the steps were also examined.

8. Distance transformation was also applied to differentiate overlapping elements. Each pixel of the binary image was marked with the distance to the nearest boundary pixel. Selecting higher values lead to the best results. 
Qualification of the crater detection process was based on a comparison with a reference layer. The reference layer was carried out by a human expert using visual interpretation method. The confusion matrix (HeIPKE et al. 1997) shows the rate of similarity and dissimilarity (Table 1). If the centroid of an extracted crater is located inside a reference crater, then the matrix value is "True Positive" (TP). If the extracted crater centroid is not located in a reference crater, then the value is "False Positive" (FP). Finally, if a reference crater remains undetected, then the value is a "False Negative" (FN). Three indicators (equations 1-3) were calculated from the values of the confusion matrix:

$$
\begin{aligned}
\text { Completeness } & =\frac{T P}{\text { Number of reference craters }} \\
\text { Correctness } & =\frac{T P}{T P+F P} \\
\text { Quality } & =\frac{T P}{F P+\text { Number of reference craters }}
\end{aligned}
$$

\begin{tabular}{|c|c|c|}
\hline Reference & Object & No Object \\
\hline Object & TP & FN \\
\hline No Object & FP & TN \\
\hline
\end{tabular}

Source: HeIPKE et al. 1997

Table 1: The confusion matrix

\section{Results}

The results of the improved adaptive area selection algorithm application on the "Rheine" dataset are shown in Table 2 - which was the test area with higher forest coverage - examined in the study (approximately $186 \mathrm{~km}^{2}$ ).

The values in the first row were calculated with a $1 \mathrm{~km}^{2}$ tile size, using the previously published method (presented in Fig. 1a); these were considered as reference values. In this case, empty tiles were deleted from the original 186 pieces, so the remaining 179 tiles contained the potential areas for selection. Applying the previous method, the investigated area was decreased to $75 \%$ of the original (Table 2 - Area \%), while the ratio of the forested to nonforested areas (Table 2 - Forested area \%) was almost unchanged. The usable mask area was approximately $27 \%$ of the remaining tiles.

Table 2 also shows the results of further stages of the new adaptive process. Each tile was split into four smaller tiles, if the ratio of the forested areas was under the threshold 
values (indicated in the Threshold column). Different threshold values were tested with minimum $500 \mathrm{~m}$ or $250 \mathrm{~m}$ tile sizes. The values in the Area and Usable masks' area columns improved as the threshold value increased, while the number of the investigated tiles also rose.

\begin{tabular}{|c|c|c|c|c|c|c|c|c|}
\hline & $\begin{array}{c}\text { Thresh- } \\
\text { old (\%) }\end{array}$ & $\mathbf{1 0 0 0}$ & $\mathbf{5 0 0}$ & $\mathbf{2 5 0}$ & Sum & $\begin{array}{c}\text { Area } \\
\mathbf{( \% )}\end{array}$ & $\begin{array}{c}\text { Forested } \\
\text { area (\%) }\end{array}$ & $\begin{array}{c}\text { Usable } \\
\text { mask's } \\
\text { area (\%) }\end{array}$ \\
\hline Reference & - & 179 & 0 & 0 & 179 & 74.9 & 99.994 & 26.7 \\
\hline & 10 & 139 & 127 & 0 & 266 & 65.8 & 99.996 & 30.3 \\
\hline & 10 & 139 & 42 & 83 & 318 & 64.3 & 99.996 & 31.1 \\
\hline & 20 & 93 & 285 & 0 & 378 & 59.6 & 99.998 & 33.5 \\
\hline & 20 & 93 & 161 & 379 & 633 & 53.7 & 99.998 & 37.2 \\
\hline & 30 & 56 & 417 & 0 & 473 & 56.4 & 99.998 & 35.4 \\
\hline & 30 & 56 & 167 & 777 & 1000 & 46.2 & 99.998 & 43.2 \\
\hline & 40 & 35 & 488 & 0 & 523 & 55.1 & 99.996 & 36.2 \\
\hline & 40 & 35 & 151 & 1065 & 1251 & 42.7 & 99.999 & 46.8 \\
\hline & 50 & 25 & 522 & 0 & 547 & 54.7 & 99.996 & 36.5 \\
\hline & 50 & 25 & 108 & 1288 & 1493 & 41.0 & 99.999 & 48.7 \\
\hline
\end{tabular}

Source: Own calculation

Table 2: Result of the improved adaptive method compared to the previous one ( $1^{\text {st }}$ row)

In the bomb crater detection methods, the circularity and distance transform were the two additional stages in the developed procedure (see above in the description of the process design). When applying these stages, the optimisation of the relevant parameters was the main challenge. It has been previously demonstrated that applying only the first 30 smoothing steps and using threshold values between 5 and 15 are adequate to detect craters (NEUBERGER et al. 2017) (cf. Table 3). Therefore, these parameter intervals were tested in the first sample area, and the changes in mean values of quality features were analysed.

\begin{tabular}{|c|c|c|}
\hline Input parameters & Tested values & Optimal values \\
\hline Resolution & $10,25,50,100,200 \mathrm{~cm}$ & $50-100 \mathrm{~cm}$ \\
\hline Threshold & $1-45 \mathrm{~cm}$ & $\begin{array}{c}\sim 10 \% \text { of the estimated depth } \\
\text { of the craters }(5-15 \mathrm{~cm})\end{array}$ \\
\hline Smoothing steps & $1-500$ & $10-30$ \\
\hline
\end{tabular}

Source: Own calculation

Table 3: Tested and optimal parameters during bomb crater detection 
The increasing mean value of correctness is shown in Figure 3, in the case of circularity examination. The 0.03 point can be defined as optimal circularity, because correctness had almost maximum value, and beyond this point values for completeness and quality significantly decreased.

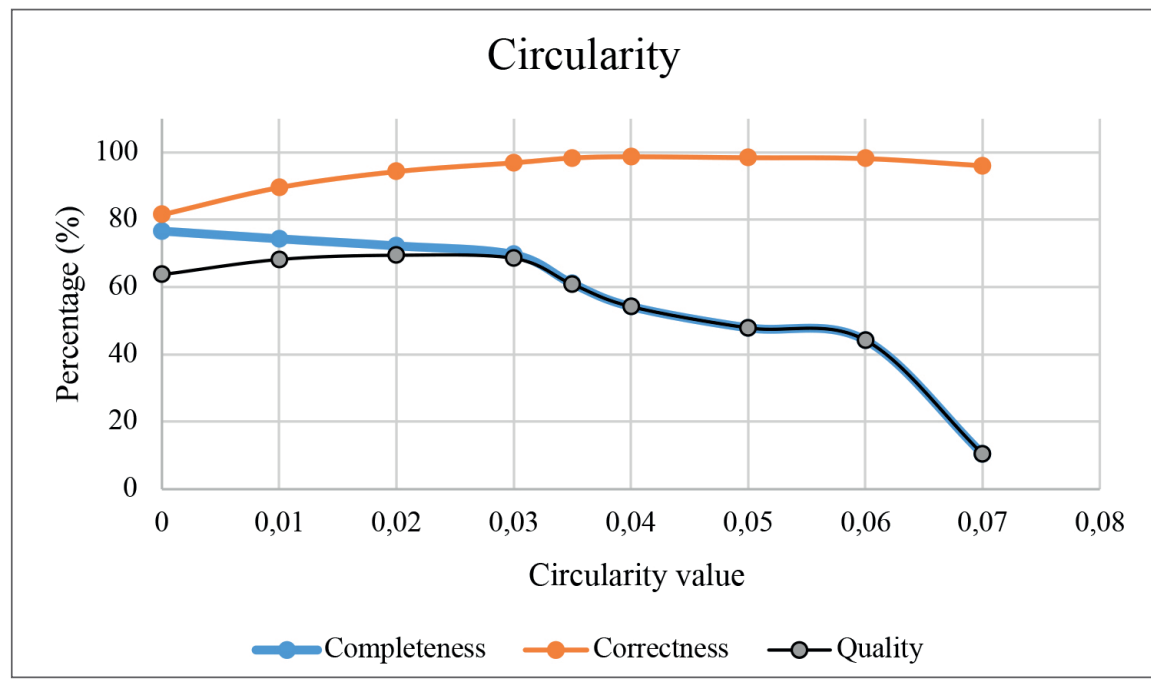

Source: Own image based on own process

Figure 3: Testing the circularity parameter in Salzgitter area

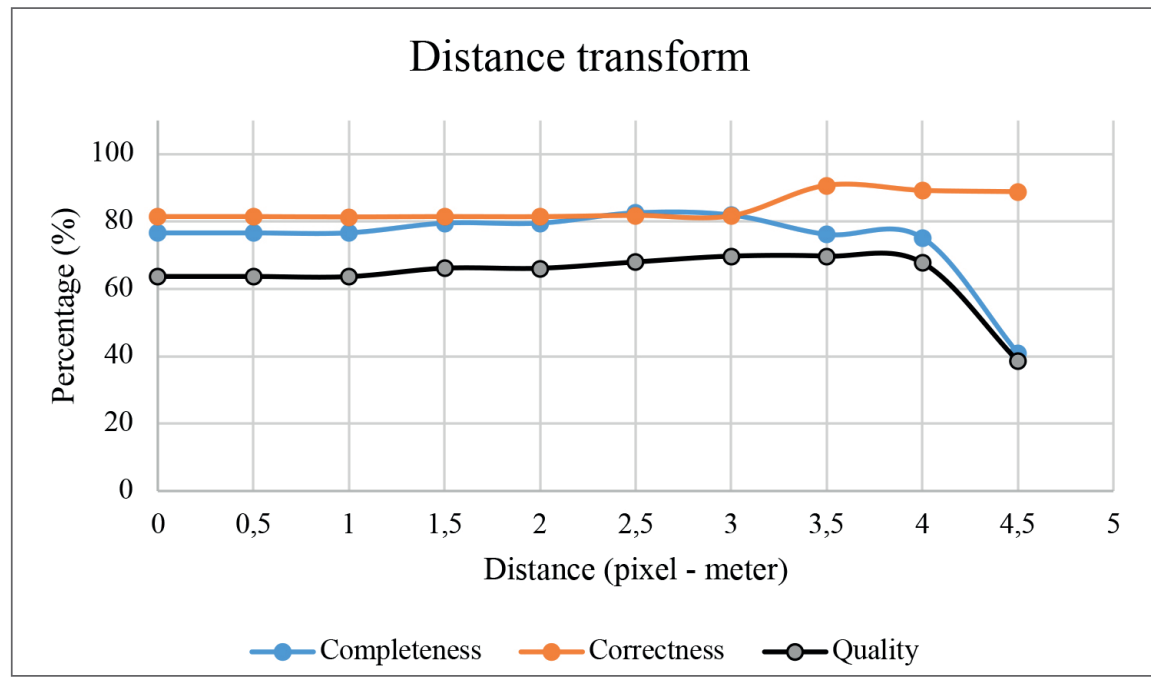

Source: Own image based on own process

Figure 4: Testing the distance transformation parameter in Salzgitter area 
The results of the tests of the distance transformation parameter are shown in Figure 4. The completeness (hence the quality) was improved until $2.5-3 \mathrm{~m}$ pixel sizes, while correctness did not change. Completeness started to decrease above these values, because the smaller FP and TP craters were removed; thus the correctness improved.

The results of the improved crater identification processes from three different sample areas are presented in Table 4. The number of reference craters (as defined by a human expert) is shown in the second column. The parameters (thresholds, number of smoothing iterations) were optimised in the first sample area but not in the second and third. As a result, there were notable differences between the first, second, and third areas, because the sizes and the depths of the craters were significantly smaller. Finally, Figure 5 shows the original DTM (left side) and the identified craters (right side) of the "Salzgitter" test area. The developed algorithm detected 31 craters (represented with pink points) from the 33 reference craters.

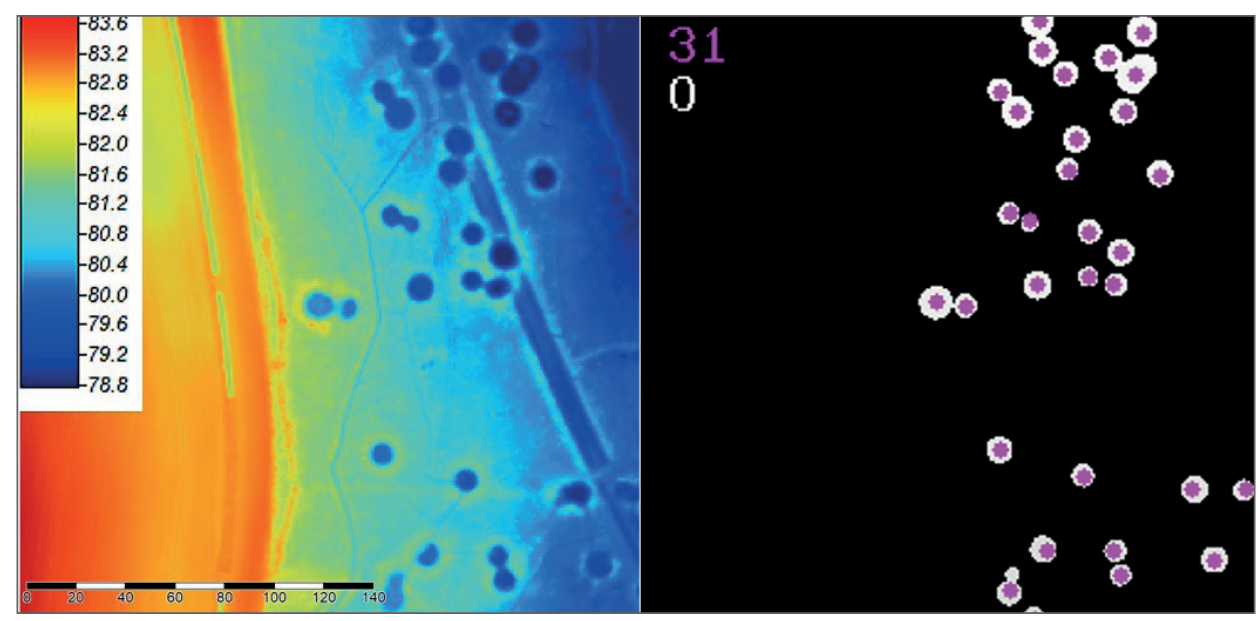

Source: Own images based on own process

Figure 5: The result of the crater detection in test area Salzgitter

\begin{tabular}{|c|c|c|c|c|c|c|}
\hline Test area & $\begin{array}{c}\text { Reference } \\
\text { craters }\end{array}$ & TP & FP & $\begin{array}{c}\text { Complete- } \\
\text { ness (\%) }\end{array}$ & $\begin{array}{c}\text { Correct- } \\
\text { ness (\%) }\end{array}$ & $\begin{array}{c}\text { Quality } \\
\text { (\%) }\end{array}$ \\
\hline Salzgitter & 33 & 31 & 0 & 93.9 & 100.0 & 93.9 \\
\hline Rheine1 & 56 & 47 & 4 & 83.9 & 92.2 & 78.3 \\
\hline Rheine2 & 37 & 27 & 21 & 73.0 & 56.2 & 46.6 \\
\hline
\end{tabular}

Source: Own calculation

Table 4: The results of the improved crater detection algorithm 


\section{Discussion}

In this section, the particular description and justification of the adaptive tile creation-based process and its methodological contribution are discussed. First, the key aim of the process was to decrease the number of valid investigated areas and processing time. With the developed adaptive tile selection procedure, it was possible to identify the appropriate tile size and number to meet the study's research objectives. Tile size and number are significant factors, because they have the potential to slow down the algorithm in different ways. Firstly, tile size influences processing time of a single raster. Secondly, a high number of tiles can increase running time of the entire algorithm, because of multiple reading-writing tasks. An additional feature and contribution of the developed procedure is that it provides an efficient way to eliminate small pixel clusters.

The first selected sample area (Emmerich am Rhein) was approximately $146 \mathrm{~km}^{2}$, which could be investigated either as 146 pieces of $1 \mathrm{~km}^{2}$ tiles or as 584 pieces of $0.25 \mathrm{~km}^{2}$ tiles. In the former case, there were 5 million points in a LiDAR file, which could lead to significant processing issues. In the latter case, however, there were 1.5 million points per $0.25 \mathrm{~km}^{2}$ tile, which made point cloud managing easier at the tile level.

The forest coverage was only $6 \%$ in this first sample investigation, which meant that the procedure had to involve a significant area reduction. The processed area was therefore reduced to $18 \%\left(0.5 \mathrm{~km}^{2}\right.$ tiles $)$ and to $30 \%\left(1 \mathrm{~km}^{2}\right.$ tiles $)$ of the original area. The second sample area (Rheine) had larger forested parts. During this second sample investigation, the downloaded file size was twice as large as in the first case (4.9 GB vs. 10.7 GB), but the total area was only 30\% larger (approximately $186 \mathrm{~km}^{2}$ ). The ratio of the forested areas was three times higher (circa 20\%). As a result of the larger wooded areas, the reduction value was proportionally changed to $55 \%\left(0.5 \mathrm{~km}^{2}\right.$ tiles $)$ and to $75 \%\left(1 \mathrm{~km}^{2}\right.$ tiles). These values could still be considered as a significant decrease, especially in the case of the smaller tiles.

The adaptive mask creation process was also applied in the second sample area. There were two notable results in this case. Firstly, very similar results were produced by the method compared to the $0.5 \mathrm{~km}^{2}$ tile based method; however, the number of files processed was lower (547 instead of 615 files). While the number of processed files is strongly dependent on the size of the investigated territory and the ratio of the forested to nonforested areas, the running time was reduced by the use of adaptive masking. Secondly, although the amount of potential area to be investigated decreased $(40 \%)$, there was a significant increase in file numbers, due to the use of smaller $250 \times 250 \mathrm{~m}$ tile sizes applied in this case. Apart from the examination of the masking methods, pixel cluster elimination thresholds were also investigated. The maximum cluster size was set as 1 , 2 , and 3 craters' of area.

Overall, the results demonstrate the following findings:

1. More effective masks can be achieved with smaller tiles, but the number of files can increase significantly.

2. The initial size of the tile has the most influence on the procedure's efficiency. 
3. Contrary to expectations, eliminating small pixel clusters at the beginning of the process or continuously during the procedure has not improved efficiency; it was sufficient to execute this step once, at the end of the algorithm. Furthermore, the elimination of the various pixel cluster sizes (50-300 pixel) has not led to significant differences in the results.

4. The most important advantage of the adaptive mask creation process was that noninformative tiles and tiles' parts could be eliminated continuously during the procedure.

5. The number of investigated files could be controlled by considering the optimal tile size and ratio of the effective mask areas to total mask areas.

6. Theoretically, the process has no limitation regarding the tile size. The ratio of the effective mask areas could be set from $0 \%$ to $100 \%$.

After selecting areas of interest, the bomb crater detection was the next step. To analyse the two stages of the developed process, it is worth noting the results of the original algorithm (Table 5). The comparison of the two tables (Table 4 and Table 5) reveal significant differences in the number of FP craters. Improving the procedure, eliminating the FP craters (circularity), and separating the overlapping craters (distance transformation) were also executed in test area 1 . There were no overlapping craters in the other two test areas, but the investigation of circularity radically decreased the number of FP craters, as it was shown in Table 4.

\begin{tabular}{|c|c|c|c|c|c|c|}
\hline Test area & $\begin{array}{c}\text { Reference } \\
\text { craters }\end{array}$ & TP & FP & $\begin{array}{c}\text { Complete- } \\
\text { ness (\%) }\end{array}$ & $\begin{array}{c}\text { Correct- } \\
\text { ness (\%) }\end{array}$ & $\begin{array}{c}\text { Quality } \\
(\%)\end{array}$ \\
\hline Salzgitter & 33 & 28 & 3 & 84.9 & 90.3 & 77.8 \\
\hline Rheine1 & 56 & 35 & 65 & 62.5 & 35.0 & 28.9 \\
\hline Rheine2 & 37 & 27 & 246 & 73.0 & 9.9 & 9.5 \\
\hline
\end{tabular}

Source: Own calculation

Table 5: The tested and the optimal parameters

As it was previously demonstrated, the developed algorithm works efficiently in the test areas; but there are several limitations, that can hinder in achieving appropriate results. Firstly, the amount of data can be critical, for example according to our experiences, the ArcGIS has a 200 files limit in processing, which can make difficulties in case of nationwide investigation. Considering the crater detection process, overlapping or asymmetrically filled up craters, craters with significantly different sizes in the same location, and craters situated on linear objects (e.g. road, dam) still pose serious problems.

\section{Application}

As it was mentioned previously, risk mapping is one of the potential applications of detected bomb craters, where these maps represent various levels of risk. The aim of the 
risk maps is to inform the user about the spatial distribution of potential hazardous territories within the investigated area. Nowadays, unexploded bombs may still pose a serious threat. According to previous publications (BRENNER et al. 2018), approximately $10 \%$ of all dropped bombs have not exploded. In several cases, the location of these unexploded bombs can be identified on archive photographs, but the accessibility of photo archives and the photos' quality are limited.
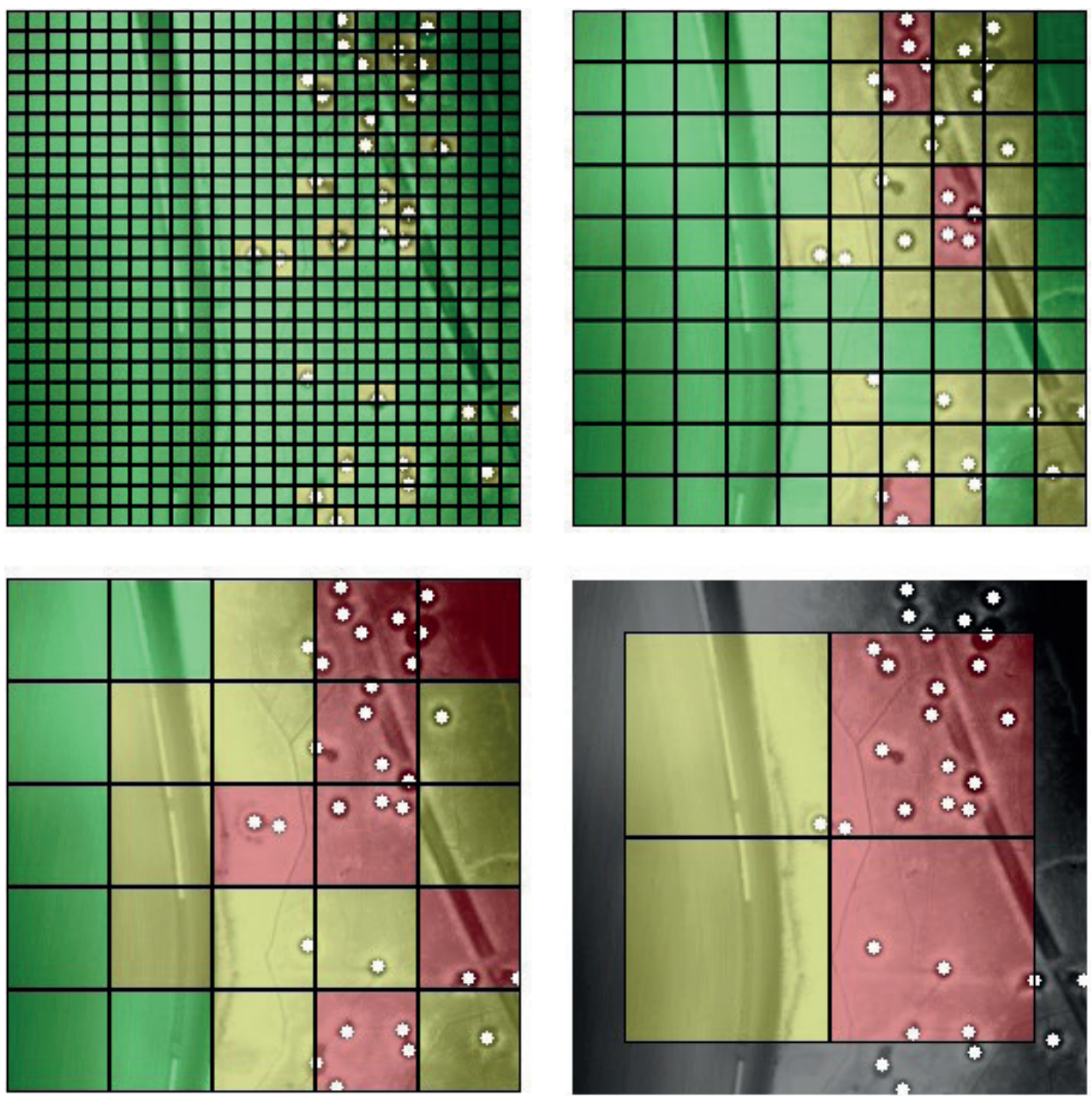

Source: Own images based on own process

Figure 6: Risk map creation with various grid sizes

Regarding typical users' needs (archaeologists, sappers, bomb squads) the risk map is grid based and coloured according to the hazard level. The colour red represents the 

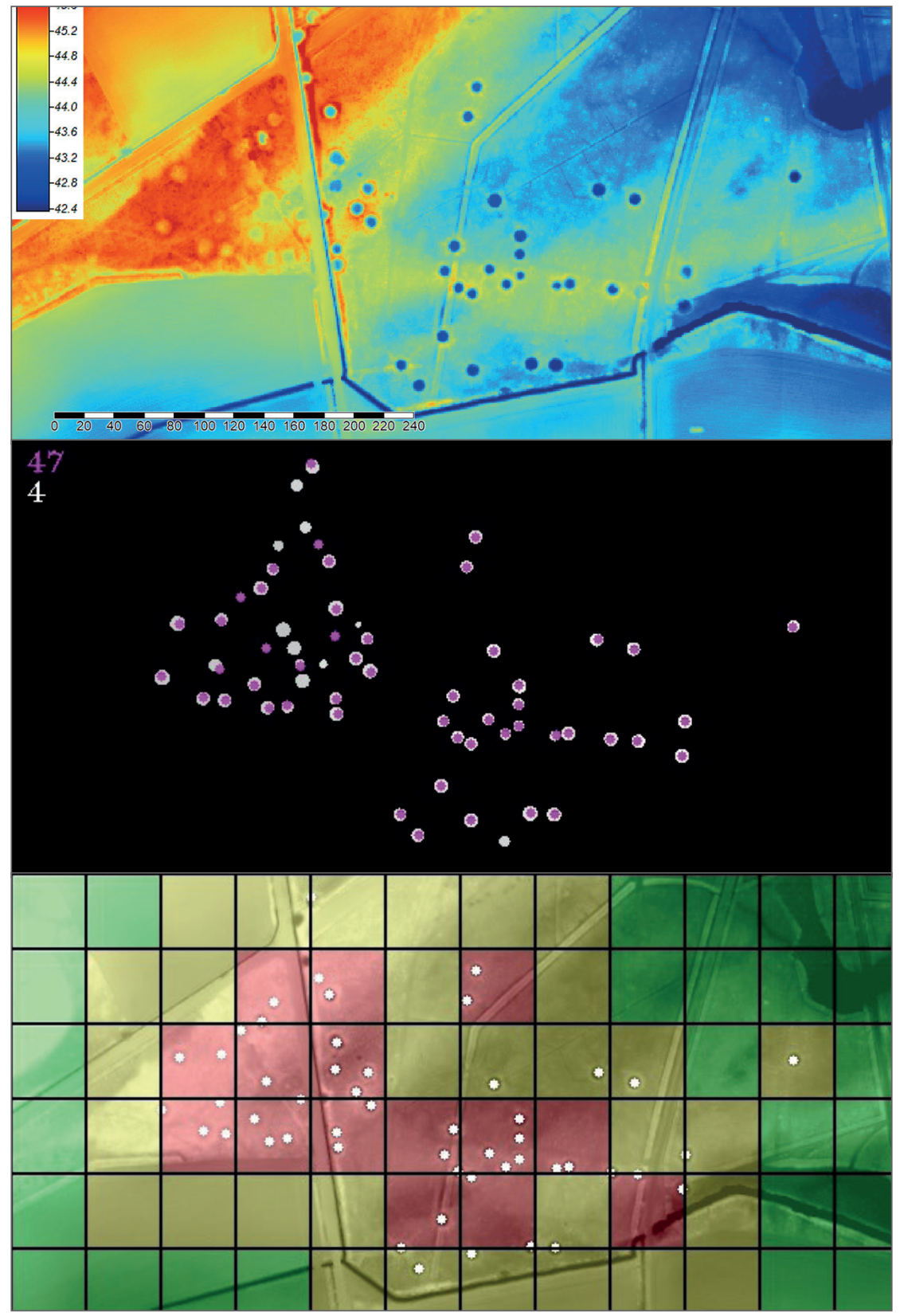

Source: Own images based on own process

Figure 7: The DTM (upper), the result of crater detection (middle) and the risk map (lower) of Rheine1 test area 
most dangerous territories, where more carters can be found. To increase the efficiency of bomb sweeping, it is recommended to begin the work at these areas. Yellow represents the territories where exactly one crater is situated. Regarding safety considerations, all neighboring grids in proximity to the red grids are also coloured yellow. Furthermore, if a single bomb crater was situated near to any of the grid's edge (inside a $10 \mathrm{~m}$ buffer), the neighboring grid connected to this particular edge was also filled with yellow. The remaining safe grids were coloured green.

Various grid resolutions were investigated and the $50 \mathrm{~m}$ resolution was proven to be optimal. On the one hand, in the case of higher resolution, the sizes of the areas to be swept were too small, compared with practical experiences. Additionally, narrow (10-20 m wide) "green" corridors can appear (Fig. 6), which cannot be considered safe areas because of their size. On the other hand, the use of lower resolution resulted in overly large hazardous grids, and in practice the cost of the investigation and cleaning of these areas grows radically.

Naturally, the automated process can be applied with various resolutions, according to the users' needs, and the size of the used map section can also be considered. If the map section's size is not perfectly divisible by the grid size (to give a whole number quotient), then the algorithm begins the process from the center of the map section as it shown lower right corner of Figure 6. Finally, the images of Figure 7 show the results of major stages during the whole process.

\section{Conclusion and future research}

The detection and identification of various historic military objects can support the reconstruction of fortresses or defense lines, and the creation of risk maps. The traditional method of military object interpretation was slow and inefficient. The aim of this research was to create a procedure based on previous studies, which allows the refined selection of potential areas for investigation from very large datasets. There were several improvements carried out in order to increase the efficiency compared to the previous research stages. The base tile size was reduced, according to the size of the potential areas, and unnecessary tiles were deleted in different stages using the developed procedure.

Using this method, the amount of data to be processed was reduced by $40-55 \%$ in the case of the test areas. Using the reduced and selected areas, DTMs could be generated. The craters' morphometry, circularity and distribution within these DTMs were considered automatically in the developed crater detection procedure. The detection and identification of the bomb craters worked efficiently in the test areas, but the process was influenced by specific parameters. The bomb crater maps can be used in various applications. An automated risk map creation process was developed, that is able to consider the potential users' needs (resolution, size of map section).

Future research plans include to automate the whole process, from data downloading to detecting craters, creating risk maps as well as improving the efficiency of the algorithms. This method can be applied not only to forested areas, but to any OSM 
layer. For example, it could be used for settlement and building layers, for the creation of 3D city models, or even for estimating of potential solar energy production, based on rooftop models (SzABó et al. 2016). Additionally, single layer data are not the only type of possible input data for the process. Generated buffer zones or the results of a GIS analysis or queries could also be used as input data. Finally, the crater detection procedure could also be used in other morphometric parameter-based tasks, such as doline formation or burial mound mapping.

\section{Acknowledgement}

\begin{tabular}{|c|}
\hline This research was supported by the ÚNKP-17-3-I \\
New International Excellence Program of the Ministry of \\
$\begin{array}{c}\text { EMBERI ERÓFORRÁSOK } \\
\text { MINISZTÉRIUMA }\end{array}$ \\
Human Capacities, Hungary
\end{tabular}

\section{References}

ArcGIS ModelBuilder (2018). http://desktop.arcgis.com/en/arcmap/10.4/analyze/modelbuilder/ what-is-modelbuilder.htm (last access: Oct. 13, 2018).

Barsi A., Lovas T., Molnar B., Somogyi A., Igazvolgyi Z. S. (2016): Pedestrian Detection by Laser Scanning and Depth Imagery. In: International Archives of the Photogrammetry, Remote Sensing and Spatial Information Sciences (ISPRS Archives), 41, pp. 465-468. DOI: 10.5194/isprsarchives-XLI-B3-465-2016

Barsi Á., Potó V., Somogyi Á., Lovas T., Tihanyi V., Szalay Z. (2017): Supporting Autonomous Vehicles by Creating HD Maps. In: Production Engineering Archives, 16, pp. $43-46$.

BERÉNYI A. (2010): Laser Scanning in Engineering Survey - An Application Study. In: International Journal for Engineering and Information Sciences, 24, pp. 39-48. DOI: 10.1556/Pollack. 5.2010.2.4.

Brenner S., Zambanini S., Sablatnig R. (2018): Detection of Bomb Craters in WWII Aerial Images. In: Proceedings of the OAGM Workshop 2018, pp. 94-97. DOI: 10.3217/978-3-85125603-1-20.

Grammer B., Draganits E., Gretscher M., Muss U. (2017): LiDAR-Guided Archaeological Survey of a Mediterranean Landscape: Lessons from the Ancient Greek Polis of Kolophon (Ionia, Western Anatolia). In: Archaeological Prospection, 24, pp. 311-333. DOI: 10.1002/ arp. 1572.

Heipke C., Mayer H., Wiedemann C., Jamet O. (1997): Evaluation of Automatic Road Extraction. In: International Archives of Photogrammetry and Remote Sensing, 32, pp. 151-160.

Isenburg M. (2013): LASzip: Lossless Compression of LiDAR Data. In: Photogrammetric Engineering \& Remote Sensing, 79, 2, pp. 209-217.

Juhász A., Neuberger H. (2016): Remotely Sensed Data Fusion in Modern Age Archaeology and Military Historical Reconstruction. In: International Archives of the Photogrammetry, Remote Sensing and Spatial Information Sciences (ISPRS Archives), 41, pp. 281-286. DOI: 10.5194/isprsarchives-XLI-B5-281-2016. 
Juhász A., Neuberger H. (2018): Automatic Selection of Potential WWII Bombed Areas by Using Spatial Data. In: Pollack Periodica, 13, pp. 173-183. DOI: 10.1556/606.2018.13.2.17.

Kruse C., Neuberger H., Rottensteiner F., Hoberg T., Ziems M., Huth J., Heipke C. (2017): Automatische Detektion von Bombenkratern in Kriegsluftbildern mittels markierter Punktprozesse [Automatic detection of bomb craters in aerial photographs from World War II by marked point processes]. In: KeRSTEN T. P. (ed.): Kulturelles Erbe erfassen und bewahren - Von der Dokumentation zum virtuellen Rundgang. Vorträge, 37. Wissenschaftlich-Technische Jahrestagung der Deutschen Gesellschaft für Photogrammetrie, Fernerkundung und Geoinformation (DGPF) in Würzburg (= Publikationen der DGPF, 26). Hamburg, DGPF, pp. 245-261.

Marchionni P., Findlay P., Dunning A., Southall H., Heally R., Aucott P., Ladd B., Brown M. (2013): Bomb Sight - Mapping the World War 2 London Blitz Bomb Census. http:// www.bombsight.org/ (last access: July 5, 2018).

Merler S., Furlanello C., Jurman G. (2005): Machine Learning on Historic Air Photographs for Mapping Risk of Unexploded Bombs. In: Roli F, Vitulano S. (eds.): Image Analysis and Processing - ICIAP 2005 (= Lecture Notes in Computer Science (LNCS) (including subseries Lecture Notes in Artificial Intelligence and Lecture Notes in Bioinformatics), 3617). Berlin - Heidelberg, Springer, pp. 735-742. DOI: 10.1007/11553595_90.

Neuberger H., Juhász A., Kruse C. (2017): Automatic Detection of World War II Objects Based on Air-borne LiDAR Data. Conference Paper. VIII. Debreceni Egyetem Térinformatikai Konferencia és Szakkiállitás, Debrecen 2017: Az elmélet és a gyakorlat találkozása a térinformatikában [VIII. GIS-Conference and Exhibition Debrecen 2017: Meeting Theory and Practice in Space Information, Theory Meets Practice in GIS]. Debrecen, Debrecen University Press, pp. 259-265.

OpenGeodata NRW (2016). https://www.opengeodata.nrw.de/produkte/(last access: Aug. 21, 2018). OpenStreetMap (2018). https://www.openstreetmap.org/about (last access: Aug. 18, 2018).

Salamunićcar G., Lončarić S. (2008): Open Framework for Objective Evaluation of Crater Detection Algorithms with First Test-field Subsystem Based on MOLA Data. In: Advances in Space Research, 42, pp. 6-19. DOI: 10.1016/J.ASR.2007.04.028.

Stoker J., Abdullah Q., Nayegandhi A., Winehouse J. (2016): Evaluation of Single Photon and Geiger Mode Lidar for the 3D Elevation Program. In: Remote Sensing, 8, pp. 767. DOI: $10.3390 / \mathrm{rs} 8090767$.

Szabó S., Enyedi P., Horváth M., Kovács Z., Burai P., Csoknyai T., Szabó G. (2016): Automated Registration of Potential Locations for Solar Energy Production with Light Detection And Ranging (LiDAR) and Small Format Photogrammetry. In: Journal of Cleaner Production, 112, pp. 3820-3829. DOI: 10.1016/J.JCLEPRO.2015.07.117.

Telbisz T., Látos T., DeÁk M., Székely B., Koma Z., Standovár T. (2016): The Advantage of Lidar Digital Terrain Models in Doline Morphometry Compared to Topographic Map Based Datasets - Aggtelek Karst (Hungary) as an Example. In: Acta Carsologica, 45, pp. 5-48. DOI: 10.3986/ac.v45i1.4138.

Virtanen J.-P., Kukko A., Kaartinen H., JaAkkola A., Turppa T., Hyyppä H., Hyyprä J. (2017): Nationwide Point Cloud - The Future Topographic Core Data. In: ISPRS International Journal of Geo-Information, 6, 8, article 243, 18 pages. DOI: 10.3390/ijgi6080243.

Wigand C., Geitner C. (2010): Flachgründiger Abtrag auf Wiesen- und Weideflächen in den Alpen (Blaiken) - Wissensstand, Datenbasis und Forschungsbedarf [Shallow Erosion on Grasslands and Pastures of the Alps (Blaiken) - State of the Art, Data Base and Demand for Research]. In: Mitteilungen der Österreichischen Geographischen Gesellschaft, 152, pp. $130-162$. 
Zlinszky A., Molnár B., Barfod A. S. (2017): Not All Trees Sleep the Same - High Temporal Resolution Terrestrial Laser Scanning Shows Differences in Nocturnal Plant Movement. In: Frontiers in Plant Science, 8, article 1814, 25 pages. DOI: 10.3389/fpls.2017.01814. 